\title{
THE RELATIONSHIP BETWEEN SERVICE QUALITY, CLIENT SATISFACTION, PERCEIVED VALUE AND CLIENT LOYALTY: A CASE STUDY OF FLY EMIRATES
}

\author{
Ashraf Jahmani \\ Al Falah University. Dubai. UAE \\ https://orcid.org/0000-0001-8017-2918 \\ Islam Bourini \\ Al Falah University. Dubai. UAE \\ https://orcid.org/0000-0001-8410-4955
}

Omar A. Jawabreh

The University of Jordan. Jordan

http://orcid.org/0000-0001-5647-895X

\begin{abstract}
Client loyalty is one of the biggest challenges for the airline industry and marketers are seeking information on how to build client loyalty. This study will explore the relationship between service quality, client satisfaction, perceived value and client loyalty in the airline industry. The purpose of this study is to develop and implement a method for airline to identify attributes that will increase client loyalty. 384 respondents participate in this study and questionnaires were distributed randomly to passengers traveling by Emirates. In particularly a deductive approach adapted to collect specific quantitative information to accept or reject the hypothesis. Current study applies Structural Equation Modeling SEM-PLS to investigate the relationship among the constructs in proposed model. This study found that service quality has appositive relationship on passengers' satisfaction and client loyalty and negative relationship on perceived value and client loyalty. The results of this study indicated that service quality and passenger's satisfaction are important factors effect of client loyalty. In conclusion Emirates must be able to understand the importance of service quality and passenger's satisfaction to fulfill the client loyalty and improve the service quality that make most significant in airline industry.
\end{abstract}

Keywords: Satisfaction; service quality; perceived value; client loyalty; airlines.

Fecha de recepción: 6 de enero de 2019.

Fecha de aceptación: 30 de julio de 2019.

* Al Falah University. Dubai. UAE. E-mail: Ashraf.jahmani@afu.ac.ae.

**Al Falah University. Dubai. UAE. E-mail: Islam.burini@afu.ac.ae

*** Department of Hotel Management. Faculty of Tourism and Hospitality. The University of Jordan. Jordan.E-mail: o.jawabreh@ju.edu.jo 


\section{La relación entre la calidad del servicio, la satisfacción del cliente, el valor percibido y la fidelidad del cliente: un estudio de caso de Fly Emirates}

\section{RESUMEN}

La lealtad del cliente es uno de los mayores desafíos para la industria de las aerolíneas. Por eso, los profesionales de marketing están buscando información sobre cómo desarrollar la lealtad del cliente. Este estudio explorará la relación entre la calidad del servicio, la satisfacción del cliente, el valor percibido y la lealtad del cliente en la industria aérea. El propósito de este estudio es desarrollar e implementar un método para que la aerolínea identifique atributos que aumentarán la lealtad del cliente. Unos 384 encuestados participan en este estudio y los cuestionarios se distribuyeron al azar entre los pasajeros que viajaban en Fly Emirates. En particular, un enfoque deductivo adaptado para recopilar información cuantitativa específica para aceptar o rechazar la hipótesis. El estudio actual aplica el modelo de ecuación estructural SEM-PLS para investigar la relación entre los constructos en el modelo propuesto. Este estudio encontró que la calidad del servicio tiene una relación positiva en la satisfacción de los pasajeros y la lealtad del cliente. Por otro lado tiene una relación negativa en el valor percibido y la lealtad del cliente. Los resultados de este estudio indicaron que la calidad del servicio y la satisfacción del pasajero son factores importantes que afectan a la lealtad del cliente. En conclusión, Fly Emirates debe ser capaz de comprender la importancia de la calidad del servicio y la satisfacción del pasajero para cumplir con la lealtad del cliente y mejorar la calidad del servicio que es más importante en la industria de las aerolíneas.

Palabras clave: Satisfacción; calidad del servicio; valor percibido; fidelización del cliente, líneas aéreas.

\section{INTRODUCTION}

Airline industry is an increasingly growing industry and it has developed to become one of the most common means of travel (Law, 2017). Specifically, airline industry facilitates tourism and contribution to the growth of businesses which depend on airlines, such as hotels, restaurants and car hire operators (Lupiyoadi and Putra, 2014). Currently, passenger's loyalty in the airline industry is becoming ever important and relevant due to the fact that the delivery of high quality service is essential for airlines survival and crucial to the competitiveness of the airline industry (Ganiyu, 2016). To achieve client loyalty a high level of client satisfaction and high standard of service quality should be delivered by the service provider (Reshidi, 2013), since service quality is considered the basis for client satisfaction and client loyalty (Abu Rumman et al., 2013; Jawabreh, 2017a; Alananzeh et al., 2018; Clemes et al., 2008).

Client loyalty plays a very crucial role for achieving competitive advantage in any organization. Olsen and Johnson (2013) found that client loyalty has an incredible impact on business profits. Azad et al. (2014) found that client loyalty is one major driver of success in tourism industry. Recently many studies have growing interest in research on client loyalty. Client loyalty defined by Oghojafor et al. (2016) as the adherence of clients 
to a company. According to Ganiyu (2016) there is a relationship between client loyalty, service quality, client satisfaction and perceived value. Bowen and Chen (2001) have pointed out that two effective means of generating client loyalty are to delight clients and to deliver superior value derived from services quality. Gures et al. (2014) state client loyalty created when clients become advocate of an organization without any incentive.

Keeping a strong client relation is a challenge for services (Karatepe, 2004). Oliver (1999) found loyal clients had higher purchases than non-loyal clients. Ravald and Grdnroos (1996) found the loyal clients have a definite impact on their intention to continually stay with, or to leave, an organization. According to Gronroos (2009) a loyal client is regarded as a type of competitive advantage for an organization. Chand and Yeh (2017) assure that loyal clients cost less to serve in part because they know the service and require less information. Therefore, loyal client has explained the service to other clients. Rashidi (2013) state loyal client not only requires less information themselves, they also serve as an information source for other. Yang and Peterson(2004) found loyal clients often will be revenues generator and demand less time and attention from the firms they patronize.

Researchers have found a strong relationship between client satisfaction and client loyalty (Ganiyu, 2016). According to Lee et al. (2001) the most effective means of generating client loyalty are to satisfy clients derived from superior services quality. Ganiyu et al. (2012) argued that client satisfaction and loyalty are not directly correlated, particularly in competitive business environment because there is a big difference between satisfaction and loyalty. In addition, Neal (1999) argues that perceived value can significantly influence client loyalty through such determinants as client satisfaction. Yang and Peterson (2004) found this further highlight the critical role of perceived value for achieving client loyalty.

This research has been conducted to examine the relationship between service quality, client satisfaction, perceived value and client loyalty. Many research esh ad investigated these relations in a single framework but within the airline industry, the current study will explore the relationship between service quality, client satisfaction, perceived value and client's loyalty by assessing the impact of client satisfaction and perceived value towards service quality. Further, the current study mainly emphasizes on understanding client's loyalty by determining the impact of service quality dimensions, client satisfaction, and perceived value which in turn provides practical insights for airline managers into how to engage the passenger and build a mutual relationship. Thus, exploring these associations will help to identify a variable that is potentially powerful and will help airlines to increase the client's loyalty.

This study initiative examined exactly what goes to make up passenger loyal as well as how loyal clients were with the service provided by the airline under consideration. The current study extends the knowledge of client loyalty be developing a model which clarifies the relationship between service quality, client satisfaction, perceived value, and client loyaltywhich in turn provides practical insights for airline managers into how to engage the passenger and build a good relationship. Based on the results client might has some expectations before receiving a service from emirates airline, and suppose that if a client receive these expectations a perceived value will created based on his satisfaction then he will be loyal (Jawabreh and Al Sarayreh, 2017). But if there are a gap among services packages provided by emirates airlines then might will not meet 
clients' expectations specially the difference between economic and business class. Thus, emirates airline required to change their policy regarding the economic services by improving the service design. Indeed, emirates airlines required to take in consideration passengers' satisfaction at economic level since it's influencing repurchase intentions and behavior, which in turn leads to sufficient profits and revenue for emirates airline. The study identifies the fact as well as the outcomes of airline passengers' loyalty with service, and concludes that superior service quality and client satisfaction lead to passenger loyalty. The study has contributed to the knowledge of relation between client loyalty, client satisfaction and service quality in a specialized area of the airline industry. Thus further this research indicates client satisfaction plays a moderating role between service quality and client loyalty (Jawabreh et al., 2018). This study found that service quality has appositive relationship on passengers' satisfaction and client loyalty and negative relationship on perceived value and client loyalty. The result of this study indicated that service quality and passengers' satisfaction are an important factor effect of client loyalty. In conclusion Emirates must be able to understand the importance of service quality and passengers' satisfaction to fulfill the client loyalty and improve the service quality that makes the most significant in airline industry.

\section{LITERATURE REVIEW}

The literature of service quality, client satisfaction, perceived value and client loyalty is first reviewed to develop conceptual foundations for the present study. Next, a model integrating key variables from studies of service quality, client satisfaction, perceived value and client loyalty is proposed and empirically tested in the airline industry.

\subsection{Client loyalty}

One of the essential concerns of business nowadays to increase market share on a global perspective and to reach that goal there are many ways, one of these waysis gaining client loyalty, in other words business owner looking for more thansatisfy and delight clients, they make extra efforts to transform their clients to loyalty level (Evans, 2015). Moreover, quality management, operations, and marketing scholars still show interest on client loyalty (Boakye et al., 2017). Clients'loyalty will lead to reduce marketing costs, reducing transaction costs, reducing the cost of replacing the client, increasing sales, information from positiveword of mouth, and reducing the cost of failure (Oliver, 1999). Severalstudies regarding client loyalty defined it as a non-random behavior shown bythe purchase routine. Hill (1996) defines client loyalty as a behavior that is intended to purchase based on the routine decision-making units, other studies addressed client loyalty as attitudinal loyalty as a psychological facet of client loyalty (Reshidi, 2013). Aydin and Ozer (2005) stated that client loyalty is reflecting the re-purchase intention, resistance to switching to other competitor's products and a willingness to recommend the service or product to others. Further, several scholars as Mandhachitara and Thong (2011) and Bosque (2013) define the operational definition under two main aspects; behavioral and attitudinal of client loyalty as retaining the old clients and 
attracting new clients, mean includes clients' repurchase intention (behavioral loyalty) and their positive willingness to recommend company's products and services to others (attitudinal loyalty). Previous scholars were observed that the characteristics of loyal clients are undertaking regular re-purchase; recommend the services to others, showing resistance to the attraction of similar products from competitors (Griffin, 1995). Chang and Yeh (2017) measured client loyalty based on a survey adopted from Bosque (2013) the survey combines six items that reflect both the behavioral and attitudinal aspects of client loyalty, and the survey items were rated on 5 point Likert scale.

\subsection{Perceived value}

There are several definitions of client perceived value According to Woodruff (1997), the client's perceived value defined as client's preference for an evaluation of those product attributes, performances, and consequences that help to achieve the client's goals and purposes in a specific circumstance. Thus, perceived value based on client experience of provided service and whether its conform to the expectations. Other scholars demonstrate that clients are ready to make sacrifice if the product or service provided deserve to do so, according to Dumond (2000) he demonstrates that client's value philosophy involves trade-off process between what client receives, benefits and any worthy things, and what he or she ready to gives for acquiring product or service, money. Indeed, this lead to the equation of client value is the total of benefits minus the money that lead to gain a product or service to meet certain needs. According to Chang and Wildt (1994) perceived value consider as an essential contributor to client's purchase intention. Moreover, Sirdeshmukh et al., (2002) addressed that behavioral intentions of loyalty toward the service provider might be motivated as long as such relational exchanges provide superior perceived value to the client. According to above previous empirical research current study hypothesis developed as:

H1. Client loyalty will be positively influenced by perceived value.

\subsection{Client Satisfaction}

As client satisfaction heavily investigated by previous empirical studies within product and service context, but according to Oliver(1999) client satisfaction still considers as an essential factor to contribute on client's loyalty. Starting from Ganiyu et al. (2012) they defined generally client satisfaction as a cognitive reaction that surfaces in the form of a response to a single or prolonged set of service encounters. More specifically within the context of the current study Anderson et al., (1994) defined client satisfaction as a client' overall evaluation of their total purchase and consumption experiences with the service they choose to have (Jawabreh, 2017b). Current study will investigate the impact of client satisfaction on client loyalty by surveying Emirates airlines services. Many studies investigate client satisfaction so far Coyne (1989) stated that client loyalty is low when client satisfaction is low which reveal a weak relationship and intermediate client loyalty relationship level when client satisfaction is intermediate and strong when client satisfaction is high. Another study by Fornell (1992) addressed that a high client satisfaction will 
increase client loyalty as well as decrease clients' intention to go for other competitor's product. Within the context of current study there are several empirical studies on passengers which indicated that passengers' satisfaction has significant effect on passenger's loyalty (Lai and Chen, 2011). Similarly, another study approved a significant relationship between satisfaction and loyalty (Ratanavaraha et al., 2016). Indeed, studies conducted by several authors such as Mohsan et al. (2011) and Degirmenci et al. (2012) reveled that client satisfaction has a positive relationship with client loyalty. Moreover, they addressed that companies within airline industry need to be more emphasize on clients' needs and demands to survive within dynamic competitive environment. Accordingto above previous empirical research such as Oliver, 1999; Zeithaml et al., 1996; Coyne, 1989; Lai and Chen, 2011 current study hypothesis developed as:

$\mathrm{H} 2$. Client loyalty will be positively influenced by client satisfaction.

\subsection{Service Quality}

Service quality is defined as clients' overall consumption experiences of the service (Aydin and Ozer, 2005). In this regard, the current study will investigate the experience of clients of Emirates airline by investigate the relationship between service quality and clients' loyalty. Based on the previous empirical researches there is a lack of research studying client loyalty within UAE context especially within airlines industry. Previous empirical researches have indicated that service quality have several effects on client loyalty depending on study context (Cronin et al., 2000). For instance, previous studies have shown that service quality influences client satisfaction and loyalty (Lai and Chen, 2011). Another empirical study shown a direct effect of service quality on client loyalty demonstrated (Mandhachitara and Poolthong, 2011). Parasuraman et al. (1988) addressed that several scholars demonstrated service quality as an attitude formed based on difference between clients' expectations regarding a service to be received and perceptions of the service being received. Similarly, Zeithaml (2000) hypothesized that a client's behavioral intentions like repeat purchase affected by service quality. Accordingto above previous empirical research such as Lai and Chen, 2011; Mandhachitara and Poolthong, 2011; Kiumarsi, Isa and Jayaraman, 2015 current study hypothesis developed as:

H3. Client loyalty will be positively influenced by service quality.

Airlines can achieve competitive advantage by maintaining and developing service quality, which can then lead to client satisfaction trough emphasize on service quality dimensions such as reliability, responsiveness, empathy, assurance, tangibles. Anderson and Mittal (2000) stated that a client's attitude to recommend a company's product or service through marketing by word of mouth depends upon the level of product or service quality. Indeed, based on Aydin and Ozer (2005) and Lai and Chen (2011) service quality influences client satisfaction by his experience of received services depending on quality level. According to above previous empirical research, current study hypothesis developed as:

H4: Client satisfaction will be positively influenced by service quality

Recently, clients looking to increase their value of received services which indicate that they become rational. Clients have the desires to those services that offer them 
highly satisfaction and utilization level in term of quality (Zameer et al., 2015). In other words, perceived value considers as a clients' assessment of the product or service received with the expectations of that product or service and how that become a valuable in their perspective (Leifu et al., 2015). A study conducted by (Zameer et al., 2015) to investigate the role of service quality in perceived value and the results revealed that service quality have significant effect on the client perceived value. Another study by Malik et al. (2011) suggests service quality influence the client perceived value within as well.

Despite the enormous research on service quality, there is a lack of any research combined service quality and client perceived value towards client loyalty within service sectors (Abdelfattah et al., 2015). Moreover, service qualities towards the clients' perceived value of services or products becomes more critical and need more emphasize from researchers within service sectors (Abdelfattah et al., 2015) and (Dobre et al., 2013). According to above previous empirical research (Zameer et al., 2015) and (Malik et al., 2011) current study hypothesis developed as:

H5. Perceived value will be positively influenced by service quality

Several researchers argued that client satisfaction might be achieved by reaching a value to them. Particularly, Oliver (1981) addressed that client has some expectations before receiving a service, and if he receive these expectations a perceived value will created based on his satisfaction. Once he or she clients the service, he or she then has a perception of the value received from it. Now the Difference between expectation and perceptions results in client satisfaction (Ali et al., 2015). Similarly Gounaris et al., (2007) find that client satisfaction significantly affect perceived value. Thus based on previous discussion the study proposed the following hypothesis

H6. Perceived value will be positively influenced by client satisfaction.

\subsection{Conceptual framework and hypotheses}

The researchers propose the conceptual framework guiding this study is presented in Figure1. Based on the literature that investigated relationship between Service quality, client satisfaction, perceived value and client loyalty in the airline industry (Gures et al., 2014) the model incorporated seven constructs. Service quality has been defined with five dimensions, namely Reliability, Responsiveness, Empathy, Assurance, and Tangibles. Client satisfaction was operationalized by four items: overall passenger satisfaction, attitude, impression and prompt service delivery. Perceived value has been operationalized by four dimensions namely emotional response, monetary price, behavioral price and reputation. Client loyalty was operationalized by five items: passengers repurchase intentions, recommend to others, willingness to engage in positive word of mouth and switching behavior and to tolerate on increase in price. The authors have generated six hypotheses relationships through empirical research associated with the model. These hypotheses focus on the interrelationships among service quality, client satisfaction, perceived value, and client loyalty. Arrows in the model indicate causal directions. 


\section{Figure 1}

\section{CONCEPTUAL FRAMEWORK}

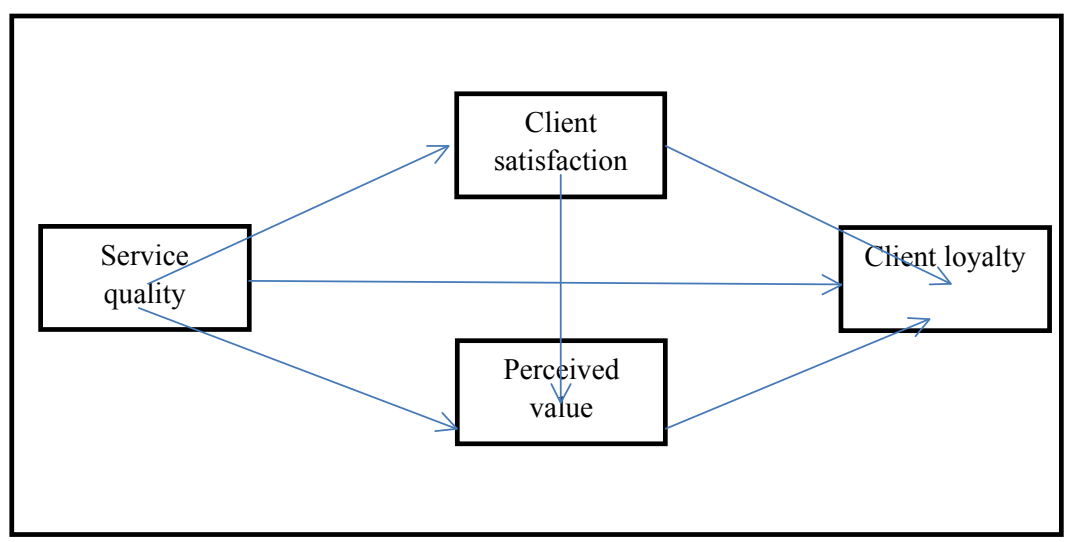

\section{METHODOLOGY}

Current study investigates the relationship between service quality, client satisfaction, perceived value and client loyalty in airline industry. Moreover, study the potential effect of service quality on client loyalty through customer satisfaction and perceived value. According to Sekaran et al. (2010) positivism research paradigm required quantitative research methods through a mono method. Hence, a self -administrated questionnaire was distributed. In particularly a deductive approach adapted to collects specific quantitative information to accept or reject the Hypothesis. Current study applies Structural Equation Modeling SEM-PLS to investigate the relationship among the constructs in proposed model.

\subsection{The instrument}

Survey instrument developed in this study consisted of a self-administered questionnaire used as a data collection instrument the questionnaire design was based on prior studies investigating airline client loyalty. Service quality was measured using a modified scale developed by Jahmani (2017) by incorporating service quality dimensions on the original SERVQUAL scale attributed to the work of Parasuraman et al. (1988). All five dimensions of service quality identified by Jahmani (2017) namely Reliability, Responsiveness, Empathy, Assurance, and Tangibles were adopted for this study. The measurement dimensions for satisfaction were adopted from Cronin et al. (2000), Olorunniwo et al. (2006), Fraering and Minor (2013), and Jahmani (2017). Client loyalty dimensions were adopted from Zeithmal et al. (1996), Mols (1998), Dehgan and Shahin (2011), and Caruana (2002) were aimed at evaluating a repurchase intensions recommend to others, willingness to engage in positive word of mouth and switching behavior and to tolerate on increase in price. Measurement dimensions for perceived value dimensions namely 
perceived quality, emotional response, monetary price, behavioral price, reputation, overall perceived value, and behavioral intentions were adopted by Levesque and Mcdougall (1996), Petrick (2002);(2003), Zeithaml et al. (1996), Gallarza and Saura (2006). Scale items for assessing key constructs, such as service quality, client satisfaction, perceived value and client loyalty were adapted from prior studies validated measures. The respondents were requested to indicate the extent to which they agree or disagree, based on recent experience, by checking the appropriate response to the questionnaire items regarding the key constructs of the study. All the questions related to each dimension were measured using five -point Likert scales for each item, anchored by 1 strongly disagree and 5 strongly agree with 3 neutrals (neither agree nor disagree) as the midpoint were utilized.

\subsection{Sample}

This study operationalized four variables service quality, client satisfaction, perceived value, and client loyalty to test the hypothesized relationship. Quantitative data collection techniques were used because data should be quantifiable to facilitate the application of statistical analysis (Malhotra, 2010). The researchers carried out an empirical study and a questionnaire was used as a primary data collection tool at Dubai International Airport in Terminal 3 by collecting data from passengers who had traveled with Fly Emirates to competed international destinations at different times and days between Feb 2018 to May 2018 in order to randomize data collection. The research was explanatory in nature because it sought to determine the cause and effect relationships between variables. A systematic random sampling method was used to select respondents at a sampling. A total of 384 passengers were respondents during the study period, all passengers were contacted after arrive to response for the purpose of the study. Of the 517 passengers contacted, 384 participated in the study, resulting in a response rate of $74.2 \%$.

\subsection{Partial Least Square PLS-SEM}

To investigate the proposed model PLS-SEM utilized to predict the construct and identify relationships between constructs (Hair et al., 2011; Reinartz et al., 2009). To the best of researcher's knowledge, no study has tested these integration models as a single model. Proposed model assess through PLS by typically follows a two-step process that is conducted as the assessment of the measurement model and the structural model (Chin, 2010; Hair et al.., 2010; Hair et al., 2011).

\subsection{Assessment of Measurement Model}

Measurement model examines the validity and reliability of the relationship between the LV and associated observable variables, whereas assessment of the structural model considers the relationships between constructs (Chin, 2010; Hair et al., 2010). To assess construct reliability, two coefficients are typically considered: Combust Reliability CR and the more common coefficient Cronbach's alpha (Bagozzi and Yi, 1988; Chin, 2010; Gotz et al., 2010). However, CR is more suitable for PLS-SEM (Hair et al., 2011). Table 
1 show that the CR for all latent variables in the measurement model is more than 0.7 . Therefore, the measurement model has internal consistency and is reliable.

Table 1

RESULTS OF THE MEASUREMENT MODEL FOR FIRST ORDER CONSTRUCTS

\begin{tabular}{lccc}
\hline Construct & CR & $\begin{array}{c}\text { Cronbach's } \\
\text { Alpha }\end{array}$ & AVE \\
\hline Client Loyalty & 0.902 & 0.855 & 0.697 \\
Client Satisfaction & 0.895 & 0.844 & 0.681 \\
Perceived Value & 0.948 & 0.937 & 0.694 \\
Service Quality & 0.911 & 0.880 & 0.637 \\
\hline
\end{tabular}

The validity of the reflective measurement model considers convergent and discriminant validity (Hair et al., 2011; Gotz et al., 2010). The AVE values of LVs should be higher than 0.5 to gain an acceptable convergent validity (Bagozzi and Yi, 1988; Hair et al., 2010; Chin, 2010). AVE is used to measure the amount of variance in an LV that is contributed from its indicators (Chin, 2010). Table 3 shows that the AVE values of all constructs of the measurement model. However, after removing the items with loading lower than 0.5 the AVE of constructs have increased.

Discriminant validity is the extent to which each construct is truly distinct from the other constructs in the model (Chin, 1998; Hair et al., 2010). Two measures must be checked to test discriminant validity. The AVE of each construct should be higher than the highest squared correlation of the construct with any other LV in the model, and an indicator's loading with its associated LV must be higher than its loading with other LVs (Fornell and Larcker, 1981; Hair et al., 2011; Chin, 2010). Moreover, table 2 present the comparison of the square root of AVE of each construct with the correlation of the other construct. Figure 2 represent construct validity as evaluated using factor loadings, and average variance extracted. Particularly, the results of convergent validity assessment in figure 2 indicate that all of the standardized loading values are above the cut-off level of 0.5 (Anderson and Gerbing, 1988). Indeed, removing the tricky indicators from the constructs, reliability, convergent validity and discriminant validity was highly acceptable for measurement model

Table 2

DISCRIMINANT VALIDITY

\begin{tabular}{lcccc}
\hline Constructs & CL & CS & PV & SQ \\
\hline CL & $\mathbf{0 . 8 3 5}$ & & & \\
CS & 0.981 & $\mathbf{0 . 8 2 5}$ & & \\
PV & 0.970 & 0.975 & $\mathbf{0 . 8 3 3}$ & \\
SQ & 0.972 & 0.971 & 0.981 & $\mathbf{0 . 7 9 8}$ \\
\hline
\end{tabular}

Note: Square roots of average variances extracted (AVE's) shown on diagonal. 
Figure 2

MEASUREMENT MODEL

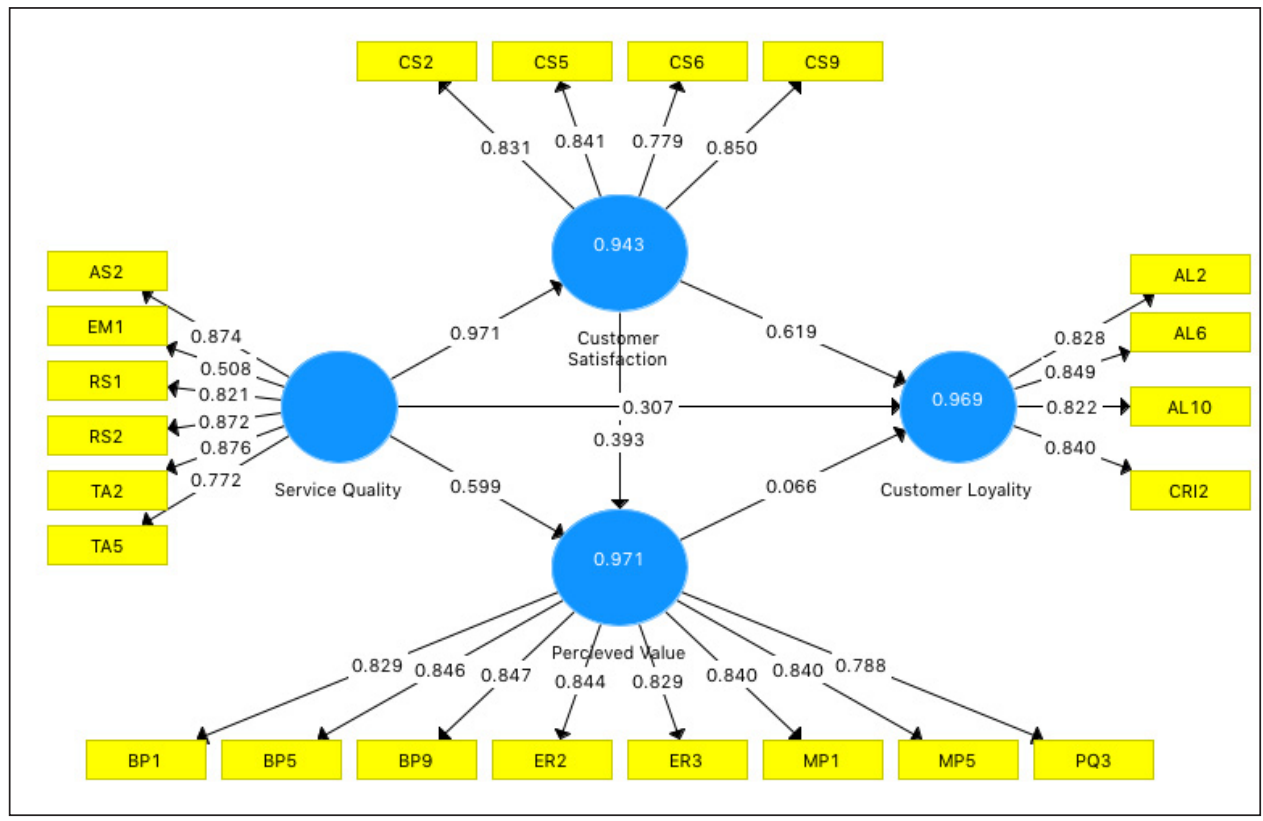

\section{GOODNESS OF FIT}

Following Hair et al. (2011), a bootstrapping method with 500 repetitions was applied to assess the significance of the indicator weights and the path coefficients. In addition, the corrected $\mathrm{R}^{2}$ of all constructs were estimated to employ a diagnostic tool to evaluate the model's goodness of fit (GOF). The goodness of fit (GOF) measure applies the geometric mean of the communality and the average $\mathrm{R}^{2}$ for endogenous constructs. The standard for evaluating the outcomes of the GOF analysis is small (0.02), medium (0.25) and large (0.36) (Hair et al., 2010). In this research, the GOF value of 0.68 (see Table 3 ) validates the proposed model of the relationship between client satisfaction, service quality and client loyalty, and signifies that the model performs relatively well. Chin, Peterson, and Brown (2008) argue that an investigator should be able to employ the magnitude of $\mathrm{R}^{2}$ and StoneGeisser's $\mathrm{Q}^{2}$ value as a criterion for the predictive significant of assessing model using PLS. The results of $\mathrm{Q}^{2}$ calculation are $0.66,0.63$ and 0.66 for CL, CS and PV respectively, indicating that they have satisfactory predictive relevance (Hair et al., 2010). Further, as Table 3 shows, the results of testing the structural model indicating that service quality, client satisfaction explain $96 \%\left(\mathrm{R}^{2}=0.96\right)$ of the variance of customer loyalty. Service quality explain $0.94 \%\left(\mathrm{R}^{2}=0.94\right)$ of the variance of client satisfaction. Service quality explain $0.97 \%\left(\mathrm{R}^{2}=0.97\right)$ of perceived value. 
Table 3

GOODNESS OF FIT INDEX

\begin{tabular}{|c|c|c|c|c|}
\hline Variables & & AVE & $\mathbf{R}^{2}$ & $\mathbf{Q}^{2}$ \\
\hline Client Loyalty & & 0.69 & 0.96 & 0.66 \\
\hline Client Satisfaction & & 0.68 & 0.94 & 0.63 \\
\hline Perceived Value & & 0.69 & 0.97 & 0.66 \\
\hline Service Quality & & 0.63 & - & - \\
\hline Average Score & & 0.67 & 0.71 & - \\
\hline AVE X R $\mathbf{R}^{2}$ & 0.47 & & & \\
\hline GoF $=\sqrt{ }\left(\mathbf{A V E} \times \mathbf{R}^{2}\right)$ & 0.68 & & & \\
\hline
\end{tabular}

\section{ASSESSMENT OF STRUCTURAL MODEL}

According to the objectives of this study, the relationships between constructs and Client Loyalty (CL) have been assessed. The following two criteria should be evaluated to obtain a preliminary assessment of the structural model (inner model): R-square (R2) measure of endogenous constructs and the path coefficients (Hair et al., 2010; Chin, 2010).

The path coefficients must be significant, and R2 is highly depended on the research area. Chin (1998) suggested 0.67, 0.33, and 0.19 measures for R2 to be considered substantial, moderate, and weak, respectively. The R2 value of endogenous construct (CL) of the current study is 0.96 . Therefore, the value is acceptable. All path coefficients are highly significant as well (See Table 4). Therefore, all hypothetical relationships are significant and supported expect Hypothesis 1 was rejected as path coefficient not significance.

The researchers decides to utilize the effect size (f 2) (Formula 5-1) is another criterion that verifies whether the effects indicated by path coefficients are high, moderate, or low. $0.02,0.15$, and 0.35 values for $\mathrm{f} 2$ represent low, moderate, and high effects, respectively (Cohen, 1988). The effect size implies whether the impact of a specific independent LV on a dependent LV is substantial or not (Chin, 2010) and is calculated according to the changes of R2 of dependent LV when the independent variable included in the model and excluded. The effect size formula is presented as:

$$
f^{2}=\frac{\mathrm{R}^{2} \text { included }-\mathrm{R}^{2} \text { excluded }(1-1)}{1-\mathrm{R}^{2} \text { included }}
$$

After the researchers run the data on PLS the effect size represents the contribution of IV on R2 of dependent LV. All relationships in the model have small, moderate and high effects which. The relationship between CS and CL has the highest effect size. Particularly, client satisfaction CS has highest significant and positive effect on client loyalty CL with path coefficient $=0.619$, and $f 2=0.541$, that is followed by effects of SQ is significant and positive where the path coefficients is 0.307 with small effect sizes equal 0.10 and lowest one is perceived value as the hypothesis rejected. 
Table 4

\section{SUMMARY OF THE PLS REGRESSION RESULTS}

\begin{tabular}{lllllll}
\hline Relationships & Variable & Coefficient & Effect Size & t-value & p-value & Result \\
\hline $\begin{array}{l}\text { In Direct } \\
\text { Relationships }\end{array}$ & $\mathrm{PV} \rightarrow \mathrm{CL}$ & 0.066 & 0.004 & 0.391 & 0.696 & H1: Not \\
& & & & & & Supported \\
& $\mathrm{CS} \rightarrow \mathrm{CL}$ & $0.619^{* *}$ & 0.541 & 9.03 & 0.000 & H2: Supported \\
& $\mathrm{SQ} \rightarrow \mathrm{CL}$ & $0.307^{*}$ & 0.10 & 2.327 & 0.020 & H3: Supported \\
& $\mathrm{SQ} \rightarrow \mathrm{CS}$ & 0.971 & & 133.357 & 0.000 & H4: Supported \\
& $\mathrm{SQ} \rightarrow \mathrm{PV}$ & $0.599^{* *}$ & & 4.440 & 0.000 & H5: Supported \\
& $\mathrm{CS} \rightarrow \mathrm{PV}$ & $0.393^{*}$ & & 2.912 & 0.004 & H6: Supported \\
\hline
\end{tabular}

$* \mathrm{P}<.05, * * \mathrm{P}<0.01$.

A bootstrapping method was used to calculate the $t$ values of the model, where values of $t$ equal to or greater than 1.96 indicated a significant level of the proposed relationship with a $\mathrm{P}$ value of less than 0.1 . The analysis of the full sample size of 384 respondents showed that the relationship between CS and CL was significant $\left(\beta=0.619^{* *}, t=9.03\right.$, $\mathrm{p}<0.01)$. Thus Hypothesis 2 supported. In contrast to our expectation, PV has no significant relation with $\mathrm{CL}(\beta=0.066 * \mathrm{t}=0.391, \mathrm{p}>0.05)$. Therefore, hypothesis 1 is not supported.

Similarly, the results also showed that the relationship between SQ and CL was significant $\left(\beta=-0.307^{*}, t=2.327, p<0.05\right)$ Supporting Hypothesis 3 . The details of these results are presented in Table 4 and Figure 3.

\section{Figure 3 \\ COEFFICIENT AND P VALUES OF VARIABLES}

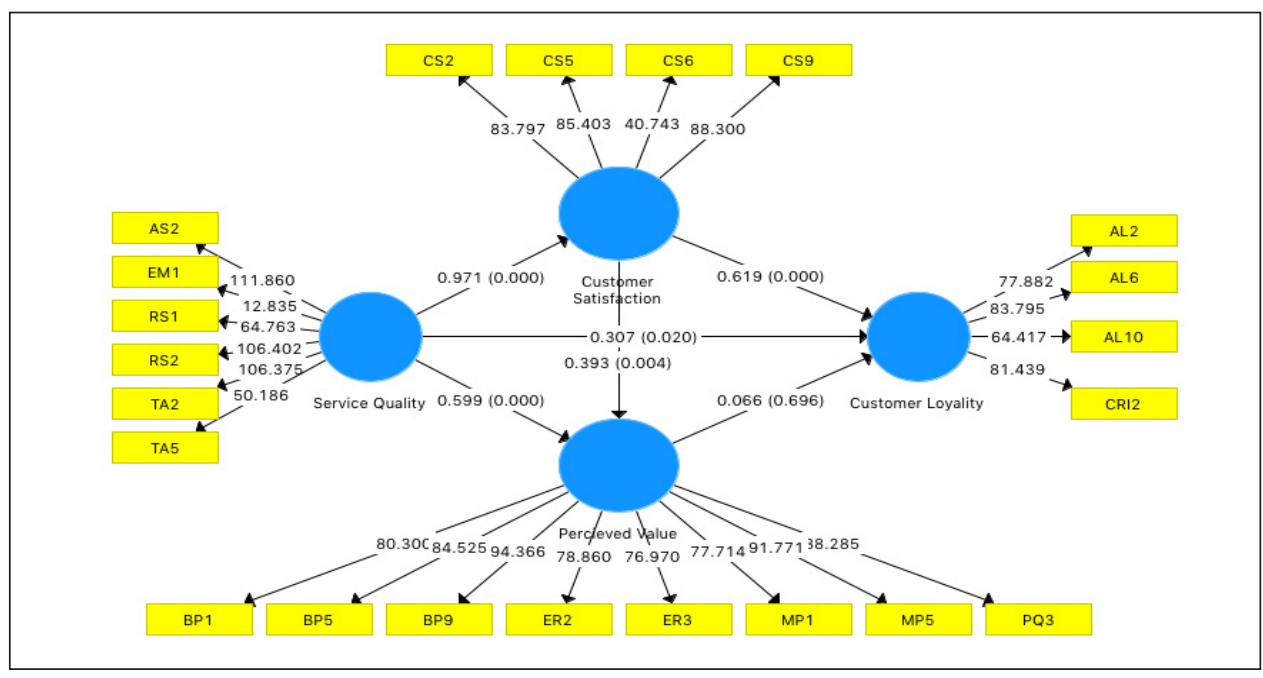




\section{DISCUSSION AND CONCLUSION}

This study investigated the relationships between service quality, client satisfaction, perceived value, and client loyalty. This relationship captured from current studies (Jahmani, 2017; Sandada and Matibiri, 2016; Hussain et al., 2015) that investigated the relationships. Hypotheses were identified and the result show client satisfaction has a significant relationship with client loyalty. This research has demonstrated that service quality absolutely impacts client satisfaction and satisfaction subsequently influence client loyalty in airline industry. This conclusion is consistent with study of (Sanadada and Matibiri, 2016) this research identified the dimensions that determine service quality as reliability, responsiveness, assurance, and tangibles that effect to passenger satisfaction and loyalty. To satisfy passengers, Emirates should make sure that they consider on five dimensions identified by the current study in providing their services in order to improve overall service quality. This finding was consistent with the result of study conducted by (Jahmani, 2017). Parasuraman and Grewal (2000) investigate that service quality is an important driver of perceived value. The results show that service quality has a direct impact on perceived value and client satisfaction. Hussain et al. (2015) suggest that high quality leads to perceived value, when clients receive good quality service they perceive it as good value.

According to Climis (2017); McDougall and Levesque (2000) airlines should design appropriate marketing strategies that promote perceived value when purchasing services since delivering value to clients contributes directly to client satisfaction, which in turn will encourages client loyalty. In contrast, this research has found an insignificant relationship between perceived value and client loyalty. This finding was not consistent with the results of study conducted by Yng and Peterson (2004). The findings suggest that client loyalty can be generated through improving client satisfaction and offering high service value. According to the literature, perceived value is the clients overall evaluation of a product based on perceptions of what is received and what is given (Zeithaml, 2000). This investigation has demonstrated that service quality has a direct impact on client satisfaction and client loyalty. Moreover, providing superior service quality is a strategic tool for client satisfaction. Therefore, the airline should make sure that they provide superior quality service in order to enhance client satisfaction and client loyalty.

On the basis of results of this study service quality and client satisfaction are significant relationships of client loyalty. Among this paradigm service quality with path coefficient (0971) has the highest effect on client satisfaction followed by client satisfaction with path coefficient $(0.619)$ effect on client loyalty. Also service quality with path coefficient (0.599) an effect on perceived value. Contrary to these findings insignificant relationship was between perceived value and client loyalty with path coefficient (0.066) findings indicates that client satisfaction was the best relationship of client loyalty. The possible explanations for this result could be attributed to the fact that Fly Emiratis had good reputation and high service quality. The implication of this research is that managers intending to develop client loyalty must satisfy clients through the delivering an outstanding service quality. In addition, the findings also support the marketing theory that highly satisfied clients repurchase more and provide positive word of mouth, resulting in improved profitability (Sandada and Matibiri, 2016). 


\section{REFERENCES}

ABDELFATTAH, A., RAHMAN, S . and OSMAN, M. (2015): “Assessing the antecedents of client loyalty on healthcare insurance products: Service quality; perceived value embedded model", Journal of Industrial Engineering and Management, vol. 8 (5), pp. $1.639-1.660$

ABU RUMMAN, M., JAWABREH, O., ALHYASAT, K. and HUSAM, H. (2013): “The impact of work environment on the average of job turnover in five-star hotels in Alaqaba city", Business Management and Strategy, vol. 4 (2), p. 111.

ALANANZEH, O., MASA'DEH, R., JAWABREH, O., AL-MAHMOUD, A. and HAMADA, R. (2018): “The impact of customer relationship management on tourist satisfaction: The case of Radisson Blue Resort in Aqaba city", Journal of Environmental Management and Tourism, vol. 2 (26), pp. 227-240 .

ALI, R., LEIFU, G., YASIRRAFIQ, M., \& HASSAN, M. (2015). Role of perceived value, client expectation, corporate image and perceived service quality on the client satisfaction. Journal of Applied Business Research, 31(4), 14-25.

AL-REFAIE, A., BATA, N.,ETEIWI, D. and JALHAM, I. (2014): "Examining Factors that Affect Passenger's Overall Satisfaction and Loyalty: Evidence from Jordan Airport”, Jordan Journal of Mechanical and Industrial Engineering, vol. 8 (2), pp. 94-101.

ANDERSON, W. and MITTAL, V. (2000): "Strengthening the Satisfaction-Profit Chain", Journal of Service Research, vol. 3 (2), pp. 107-120.

ANDERSON, E., FORNELL, C. and LEHMANN, D. (1994): "Client satisfaction, market share, and profitability: findings from sweden”, The Journal of Marketing, vol. 58 (3), pp. 53-66.

ANDERSON, C. and GERBING, W. (1988): "Structural Equation Modeling in Practice: A Review and Recommended Two-Step Approach", Psychological Bulletin, vol. 103 (3), pp. 411-423.

AYDIN, S. and OZER, G. (2005): "The analysis of antecedents of client loyalty in the Turkish mobile telecommunication market”, European Journal of Marketing, vol 39 (7), pp. 910-925.

AZAD, N., SAFAEI, M. and FARAHANI, M. (2014): “A study on the effects of different factors influencing on client loyalty, profitability and word of mouth advertisement for gaining competitive advantage in tourism industry", Management Science Letters, vol. 4 (6), pp. 1.099-1.102.

BAGOZZI, P. and YI, Y. (1988): "On the evaluation of structural equation models", Journal of the Academy of Marketing Science, vol. 16 (1), pp. 74-94.

BOAKYE, K., BLANKSON, C., VICTOR, R. and PRYBUTOK, C. (2017): “An assessment of national healthcare service delivery: a Ghanaian illustration", International Journal of Quality \& Reliability Management, vol. 34 (5), pp. 649-666.

BOWEN, J. and CHEN, S. (2001): "The relationship between client loyalty and client satisfaction", International Journal of Contemporary Hospitality Management, vol. 13 (5), pp. 213-217.

CARUANA, A. (2002): "Service loyalty: The effects of service quality and the mediating role of client satisfaction", European Journal of Marketing, vol. 36 (7-8), pp. 811-828. 
CHANG, Z. and WILDT, R. (1994): "Price, Product Information, and Purchase Intention: An Empirical Study", Journal of the Academy of marketing Science, vol. 22 (1), pp. 16-27.

CHANG, Y. and YEH, C. (2017). " Corporate social responsibility and client loyalty in intercity bus services", Transport Policy, vol. 59, pp. 38-45.

CHIN, W. (2010). How to write up and report PLS analyses. In V. E. Vinzi, W. W. Chin, J. Henseler, \& H. Wang (Eds.), Handbook of partial least squares: Concepts, methods and applications in marketing and related fields. Berlin: Springer.

CLEMES, D., GAN, C., KAO, T. and CHOONG, M. (2008): “An Empirical Analysis of Client Satisfaction in International Air Travel”, Innovative Marketing, vol. 4 (2), pp. 50-62.

CLIMIS, R. (2017): "Factors Affecting Client Retention in the Airline Industry", Journal of Management and Business Administration, vol. 24 (4), pp. 49-69.

COYNE, K. (1989): "Beyond Service Fads: Meaningful Strategies for the Real World", MIT Sloan Management Review, vol. 30 (4), pp- 69-76.

CRONIN, J., BRADY, K. and HULT, T. (2000): "Assessing the effects of quality, value, and client satisfaction on consumer behavioral intentions in service environments", Journal of Retailing, vol. 76 (2), pp. 193-218.

DEGIRMENCI, E., BASLIGIL, H., BOLAT, A. and OZDEMIR, Y. (2012): “Client Satisfaction Measurement in Airline Services Using SERVQUAL", Scientific reports, vol. 1 (5), p. 294.

DEHGHAN, A. and SHAHIN, A. (2011): "Client Loyalty Assessment: A Case Study in MADDIRAN, the Distributor of LG Electronics in Iran", Journal of Business Management and Strategy, vol. 2 (1), pp. 1-23.

DOBRE, C., DRAGOMIR, C. and MILOVAN-CIUTA, A. (2013): "A marketing perspective on the influences of waiting time and the service scape on perceived value", Management \&Marketing, vol. 8 (4), pp. 683-698.

DODDS, B., MONROE, B. and GREWAL, D. (1991): "Effect of price, brand and store information on buyers' product evaluations", Journal of Marketing Research, vol. 28 (3), pp. 307-319.

DUMOND, J. (2000): "Value Management: An Underlying Framework", International Journal of Operations \& Production Management, vol. 20 (9), pp. 1.062-1.077.

EVANS, R. (2015): "Modern analytics and the future of quality and performance excellence", Quality Management Journal, vol. 22 (4), pp. 6-17.

FORNELL, G. and LARCKER, F. (1981): "Evaluating structural equation models with unobservable variables and measurement error", Journal of Marketing Research, vol. 18 (1), pp. 39-50.

FORNELL, C. (1992): “A national client satisfaction barometer: The Swedish experience", Journal of Marketing, vol. 56 (1), pp. 6-21.

FRAERING, M. and MINOR, S. (2013): "Beyond Loyalty: Client Satisfaction, Loyalty and Fortitude", Journal of Services Marketing, vol. 27 (4), pp. 334-344.

GALLARZA, M. and GIL SAURA, I. (2006): "Value dimensions, perceived value, satisfaction and loyalty: an investigation of university students travel behavior", Tourism Management, vol. 27 (3), pp. 437-452. 
GANIYU, A., UCHE, I. and ELIZABETH, A. (2012): "Is Client Satisfaction an Indicator of ClientLoyalty?". Australian Journal of Business and Management Research, vol. 2 (7), pp. 14-20.

GANIYU, R. (2016): "Perceived Service Quality and Client Loyalty: The Mediating Effect of Passenger Satisfaction in the Nigerian Airline Industry", International Journal of Management and Economics, vol. 52 (1), pp. 94-117.

GOETZ, T., CRONJAEGER, H., FRENZELC., LÜDTKE, O. and HALL, C. (2010): "Academic self-concept and emotion relations: Domain specificity and age effects", Contemporary Educational Psychology, vol. 35 (1), pp. 44-58.

GOUNARIS, P., TZEMPELIKOS, A. and CHATZIPANAGIOTOU, K. (2007): "The relationships of client perceived value, satisfaction, loyalty and behavioral intentions", Journal of Relationship Marketing, vol. 6 (1), pp. 63-87.

GRIFFIN, J. (1995): Client Loyalty. How to Earn It, how to Keep It. New York, Lexington Books.

GRÖNROOS, C. (2009): "Marketing as promise management: Regaining client management for marketing", Journal of Business and Industrial Marketing, vol. 24 (5-6), pp. 351-359.

GURES, N., ARSLAN, S. and TUN, S. (2014): “Client Expectation, Satisfaction and Loyalty Relationship in Turkish Airline Industry”, International Journal of Marketing Studies, vol. 6 (1), pp. 66-74.

HAIR, F., BLACK, C., BABIN, J. and ANDERSON, E. (2010): Multivariate data analysis: A global perspective. (7th ed.). New York, Prentice Hall.

HAIR, F., RINGLE, M. and SARSTEDT, M. (2011): "PLS-SEM: indeed, a silver bullet", Journal of Marketing Theory and Practice, vol. 19 (2), pp. 139-151.

HILL, N. (1996): Handbook of client satisfaction measurement. Hampshire, Gower Publishing Limited.

HUSSAIN, R., AL NASSER, A. and HUSSAIN, Y. (2015): "Service quality and client satisfaction of a UAE-based airline: An empirical investigation", Journal of Air Transport Management, vol. 42, pp. 167-175.

JAHMANI, A. (2017): “The effect of royal Jordanian airline service quality on passengers' satisfaction”. International Journal of Business and Society, vol. 18 (3), pp. 519-530.

JAWABREH, O, (2017a): “Analyzing Factors Affect on Five Stars Occupational Safety in Aqaba Special Economic Zone Authority (ASEZA)", Journal of Social Sciences (COESandRJ-JSS), vol.6 (4), pp. 802-815.

JAWABREH, O. (2017b): "An exploratory study of the motives of Jordanian out bound tourism and its impact on the development of tourism in Jordan", International Journal of Applied Business and Economic Research, vol. 15 (19), pp. 443-467.

JAWABREH, O. and AL SARAYREH, M. (2017): "Analysis of job satisfaction in the hotel industry: A study of hotels five- Stars in Aqaba special economic zone authority (AZEZA)", International Journal of Applied Business and Economic Research, vol. 15 (19), p. 389.

JAWABREH, O., AL JAFFAL, T., ABDELRAZAQ, H. and MAHMOUD, R. (2018): “The Impact of Menus on the Customer Satisfaction in Restaurants Classified in Aqaba 
Special Economic Zone Authority (ASEZA)", Journal of Tourism, Hospitality and Sports, vol. 33, pp. 29-39.

KARATEPE, O. and EKIZ, E. (2004): "The effects of organizational responses to complaint on satisfaction and loyalty: A study of hotel guests in Northern Cyprus", Managing Service Quality, vol. 14 (6), pp. 476-486.

KIUMARSI, S. and JAYARAMAN, K. (2015): "Determinants of service quality on service loyalty: the mediating role of clients' satisfaction and brand equity", Problems and Perspectives in Management, vol. 13 (2), pp. 345-356.

LAI, T. and CHEN, F. (2011): «Behavioral intentions of public transit passengers-The roles of service quality, perceived value, satisfaction and involvement», Transport Policy, vol. 18 (2), pp. 318-25.

LAW, C. (2017): "The study of client relationship management in Thai airline industry: A case of Thai travelers in Thailand", Journal of Airline and Airport Management, vol. 7 (1), pp. 13-42.

LEVESQUE, T. and MCDOUGALL,G. (1996): "Determinants of client satisfaction in retail banking", International Journal of Bank Marketing, vol. 14, pp. 12-20.

LUPIYOADI, R. and PUTRA, B. (2014): “The Effects of Applying Revenue Management on Client Satisfaction in Airline Industry: An Experimental Study in Indonesia”, Asean Marketing Journal, vol. 6 (1), pp. 25-37.

MALHOTRA, N. (2010). Marketing Research-an Applied Orientation, International Edition, Sixth Edition, Pearson, Prentice-Hall.

MALIK, E., NAEEM, B. and ARIF, Z.(2011): "Impact of perceived service quality on banking clients' loyalty", Interdisciplinary journal of contemporary research business, vol. 3 (8), pp. 637-645.

MANDHACHITARA, R. and POOLTHONG, Y. (2011): “A model of client loyalty and corporate social responsibility", Journal of Services Marketing, vol. 25 (2), pp. 122133.

MARTÍNEZ, P. and DEL BOSQUE, R. (2013): "CSR and client loyalty: The roles of trust, client identification with the company and satisfaction", International Journal of Hospitality Management, vol. 35, pp. 89-99.

MCDOUGALL, G. and LEVESQUE, T. (2000): "Client satisfaction with services: putting perceived value into the equation”, Journal of Services Marketing, vol. 14 (5), pp. 392- 410.

MOHSAN, F., NAWAZ, M., KHAN, M., SHAUKAT, Z. and ASLAM, N. (2011): “Impact of client satisfaction on client loyalty and intentions to switch: Evidence from banking sector of Pakistan”, International Journal of Business and Social Science, vol. 3 (2), pp. 1.982-1.991.

MOLS, P. (1998): “The behavioral consequences of PC banking”, International Journal of Bank Marketing, vol. 16, pp. 195-201.

NEAL, W. (1999): "Satisfaction is nice, but value drives loyalty", Marketing Research, vol. 11 (1), pp. 21-23.

OGHOJAFOR, A., PATRICK, K. and AJAO, G. (2016): “Airline Service Quality Dimensions and Client Loyalty: Empirical Evidence from Air Passengers' in Lagos State", Czech Journal of Tourism: Journal of Masaryk University, vol. 5 (2), pp. 155-171. 
OLIVER, R. (1999): “Whence Client Loyalty”, Journal of Marketing, vol. 63, pp. 33-34.

OLIVER, R. (1981): "Measurement and Evaluation of Satisfaction Process in Retail Settings", Journal of Retailing, vol. 57, pp. 25-48.

OLORUNNIWO, F., HSU, K. and UDO, J. (2006): "Service quality, client satisfaction, and behavioral intentions in the service factory", Journal of Services Marketing, vol. 20 (1), pp. 59-72.

OLSEN, L. and JOHNSON, M. (2003): "Service equity, satisfaction, and loyalty: From transaction-specific to cumulative evaluations". Journal of Service Research, vol. 5 (3), pp. 184-195.

PARASURAMAN, A. and GREWAL, D. (2000). "The impact of technology on the quality- value - loyalty chain: an agenda for future research", Journal of the Academy of marketing science, vol. 28 (1), pp. 168-174.

PARASURAMAN, A., ZEITHAML, V. and BERRY, L. (1988): "SERVQUAL: a multipleitem scale for measuring client perceptions of service quality", Journal of Retailing, vol. 64 (1), pp. 12-40.

PETRICK, J. (2003): "Measuring cruise passengers perceived value", Tourism Analysis, vol. 7 (3-4), pp. 251-258.

PETRICK, J. (2002): "Development of a Multi-Dimensional Scale for Measuring the Perceived Value of a Service”, Journal of Leisure Research, vol. 34 (2), pp. 119-134.

RATANAVARAHA, V., JOMNONKWAO, S., KHAMPIRAT, B., WATTHANAKLANG, D. and IAMTRAKUL, P. (2016): "The complex relationship between school policy, service quality, satisfaction, and loyalty for educational tour bus services: A multilevel modeling approach", Transport Policy, vol. 45 (1), pp. 116-126.

RAVALD, A. and GRONROOS, C. (1996): "The value concept and relationship marketing, European Journal of Marketing”, vol. 30 (2), pp. 19-30.

REINARTZ, W., HAENLEIN, M. and HENSELER, J. (2009): “An empirical comparison of the efficacy of covariance-based and variance based SEM", International Journal of Market Research, vol. 26 (4), pp. 332-344.

RESHIDI, N., KAJTAZI, S. and ABDULLAHU, L. (2013): "Measuring service quality and a comparative analysis in airline industry", Management Science Letters, vol. 3 (1), 275-280.

SANDADA, M. and MATIBIRI, B. (2016): "An investigation into the impact of service quality, frequent flier programs and safety perception on satisfaction and client loyalty in the airline industry in southern Africa", South East European Journal of Economics and Business, vol. 11 (1), pp. 41-53.

SEKARAN, U. and BOUGIE, R .(2010): Research Methods for Business: A Skill Building Approach (5th ed.). New York, John Wiley and Sons.

SIRDESHMUKH, D., SINGH, J. and SABOL, B. (2002): "Client trust, value, and loyalty in relational exchanges", Journal of Marketing, vol. 66 (1), pp. 15-37.

WOODRUFF, R. (1997): "Client value: the next source of comparative advantage", Journal of Academy of Marketing Science, vol. 25 (2), pp. 139-153.

YANG, Z. and PETERSON. R. (2004): "Client Perceived Value, Satisfaction, And Loyalty: The Role of Switching Costs". Psychology and Marketing, vol. 21 (10), pp. 799-822. 
ZAMEER, H., TARA, A., KAUSAR, U. and MOHSIN, A. (2015): "Impact of service quality, corporate image and client satisfaction towards clients' perceived value in the banking sector in Pakistan”, International Journal of Bank Marketing, vol. 33 (4), pp. 442-456.

ZEITHAML, V. (2000): "Service quality, profitability, and the economic worth of clients: what we know and what we need to learn", Journal of the Academy of Marketing Science, vol. 28 (1), pp. 67-85.

ZEITHAML, V., BERRY, L. and PARASURAMAN, A. (1996): “The Behavioral Consequences of Service Quality”, Journal of Marketing, vol. 60 (2), pp. 31-46. 